\title{
食品の状態と貯穀害虫の発虫との関係に関する研究 \\ Studies on the Relations between the Storing Conditions of Foods and the Infestation of Stored Grain Pests.
}

\section{（その 3 ） 食品の水分と害虫の繁殖との関倸について}

(Part 3) The Relation between the Moisture of Food and

Reproduction of Insects.

(昭和 35 年 1 月 20 日受理)

\author{
渡辺至子桜井芳人 \\ (Yosiko Watanabe) (Yosito Sakurai)
}

The relation between the moisture of food and the reproduction of stored grain pests were studied.

As a test insect, Tribolium castaneum was used in the experiment.

As compared with the case of foods of more than $14 \%$ moisture, the reproduction of insects could be kept back partly in the food of to $13 \%$ moisture, and considerably in the food of less than $7 \%$ moisture. Once after the infestation of larvae, the moisture of food increased owing to the reproduction of the insects, and the reproduction of insects were carried on, in the less moist food, though the rate or speed of reproduction were reduced as compared with the case in the moist food.

先に報告したように，一度加熱した食品から虫が発生 するのは明らかに貯蔵中に外部から虫が侵入するによる ことがわかつたが，次に水分が少い場合果してどの程度

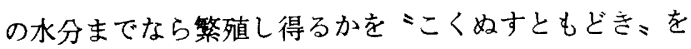
用いて試験した。

\section{実 験 方 法}

小麦粉 93 ，醭母 5 , 無機塩 2 , の配合飼料を $60^{\circ} \mathrm{C}$ で乾 燥させて水分を異にした試料を作り，100g の広口瓶に この飼料適宜と ここく好もどきミの成虫 5 対を:入れ 密栓封ろらし,なおその上を塩化ビニールのフィルムで 包み定温器内に入れた。これを $30 \sim 40$ 日間飼育した後 新たに餒化した虫(幼虫, 蛹, 成虫) の数と重量を調べ た。

なお水分の測定は $130^{\circ} \mathrm{C} 2$ 時間乾燥の方法により行 い，またごく少い水分量の試料は $60^{\circ} \mathrm{C}$ で予乾した後硫 酸デシケータ内で水分を放散させて作つた。

\section{実 験 結 果}

表 1，2，のように非常に低い水分のものでも虫は生 育するが，これは配合飼料のためかもしれないと考え表
3 のごとく小麦粉だけの飼料の試験も行つた。

表 1 飼料の水分と虫の繁殖（第一回試験）

飼料 $10 \mathrm{~g}$, 期間 42 日, 温度 $28^{\circ} \mathrm{C}$

\begin{tabular}{|c|c|c|c|c|c|c|}
\hline 水 分 & & & 幼 虫 & 蛹 & 成 虫 & 計 \\
\hline \multirow{4}{*}{2.} & & 1 & 157 & 0 & 0 & 157 \\
\hline & & 2 & 28 & 0 & 0 & 28 \\
\hline & & 3 & 26 & 0 & 0 & 26 \\
\hline & 平 & 均 & 70 & 0 & 0 & 70 \\
\hline \multirow{4}{*}{4.} & \multirow[b]{4}{*}{ 平 } & 1 & 13 & 54 & 42 & 109 \\
\hline & & 2 & 116 & 2 & 0 & 118 \\
\hline & & 3 & 88 & 0 & 0 & 88 \\
\hline & & 均 & 72 & 19 & 14 & 105 \\
\hline \multirow{6}{*}{ 9. } & & 1 & 38 & 85 & 15 & 138 \\
\hline & & 2 & 117 & 46 & 0 & 163 \\
\hline & & 3 & 25 & 91 & 53 & 169 \\
\hline & & 4 & 70 & 21 & 7 & 98 \\
\hline & & 5 & 52 & 24 & 50 & 126 \\
\hline & 平 & 均 & 60 & 53 & 25 & 139 \\
\hline
\end{tabular}




\begin{tabular}{|c|c|c|c|c|c|c|c|}
\hline 水 分 & & & 幼 白 & 虫 & 蛹 & 成 虫 & 計 \\
\hline \multirow{5}{*}{ 11. 6} & & 1 & & 77 & 161 & 34 & 172 \\
\hline & & 2 & & 6 & 44 & 61 & 111 \\
\hline & & 3 & & 11 & 49 & 104 & 164 \\
\hline & & 4 & & 2 & 17 & 86 & 105 \\
\hline & 平 & 均 & & 24 & 43 & 71 & 138 \\
\hline \multirow{6}{*}{ 15. 4} & & 1 & & 12 & 62 & 118 & 202 \\
\hline & & 2 & & 39 & 15 & 149 & 203 \\
\hline & & 3 & & 13 & 43 & 183 & 239 \\
\hline & & 4 & & 14 & 30 & 152 & 196 \\
\hline & & 5 & & 67 & 8 & 165 & 189 \\
\hline & 平 & 均 & & 19 & 31 & 153 & 206 \\
\hline
\end{tabular}

表 2 飼料の水分と虫の繁殖（第二回試験） 飼料 $5 \mathrm{~g}$ ，期間 32 日，温度 $30^{\circ} \mathrm{C}$

\begin{tabular}{|c|c|c|c|c|c|c|}
\hline 水分 & & 幼 虫 & 蛹 & 13 虫 & 計 & 重 量 \\
\hline \multirow{2}{*}{ 3. 5} & 1 & 69 & 0 & 0 & 69 & $\begin{array}{r}\mathrm{mg} \\
60.4\end{array}$ \\
\hline & 2 & 82 & 4 & 0 & 82 & 172.0 \\
\hline \multirow{2}{*}{ 5. 7} & 1 & 79 & 0 & 0 & 79 & 99.0 \\
\hline & 2 & 100 & 0 & 0 & 100 & 135.0 \\
\hline \multirow{2}{*}{ 7. 8} & 1 & 48 & 57 & 3 & 108 & 260.5 \\
\hline & 2 & 106 & 33 & 0 & 139 & $280.3^{\circ}$ \\
\hline \multirow{2}{*}{ 10. 1} & 1 & 26 & 57 & 30 & 113 & 280.5 \\
\hline & 3 & 66 & 69 & 27 & 162 & $355.0^{\circ}$ \\
\hline \multirow{2}{*}{ 13. 4} & 1 & 18 & 31 & 61 & 110 & 261.8 \\
\hline & 2 & 5 & 27 & 38 & 70 & 169.0 \\
\hline
\end{tabular}

・かびの生えたもの
表 3 飼料の水分と虫の繁殖（第三回試険） 飼料小麦粉だけ $5 \mathrm{~g}$ ，期間 34 日，温度 $30^{\circ} \mathrm{C}$

\begin{tabular}{|c|c|c|c|c|c|c|}
\hline 水 分 & & 幼 虫 & 蛹 & 成虫 & 計 & 重 量 \\
\hline \multirow{2}{*}{ 3. 9} & 1 & 119 & 0 & 0 & 119 & $\underset{98.8}{\mathrm{mg}}$ \\
\hline & 2 & 120 & 0 & 0 & 120 & 126.5 \\
\hline \multirow{2}{*}{ 5. 1} & 1 & 102 & 0 & 0 & 102 & 44.0 \\
\hline & 2 & 98 & 2 & 0 & 98 & 111.0 \\
\hline \multirow{2}{*}{ 8. 1} & 1 & 80 & 5 & 0 & 85 & 135.9 \\
\hline & 2 & 129 & 3 & 0 & 132 & 156.5 \\
\hline \multirow{2}{*}{ 10. 4} & 1 & 83 & 6 & 0 & 89 & 128.5 \\
\hline & 2 & 43 & 4 & 0 & 47 & 87.2 \\
\hline \multirow{2}{*}{ 14. 8} & 1 & 124 & 6 & 0 & 130 & 183.1 \\
\hline & 2 & 115 & 0 & 0 & 115 & 154.5 \\
\hline
\end{tabular}

以上のごとく水分が $14 \%$ 以上のものに比へ， 7 13\% のものはやや， $7 \%$ 以下のものは大分繁殖は扮さえられ るがある程度幼虫が発生した後は, 虫が生育することに より飼料の水分が増し，水分の多いものに比心゙少いもの は発生する迄がおくれても全然繁殖し得ないということ はない。

初期水分 2.8 上いう低い水分のものでも繁殖し得た。 （農林省食糧研究所）

\section{酵母細胞膜よりグルコマンナンー蛋白睤複合体の分離}

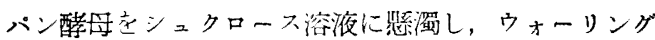
ブレンダーを用いて，低温で磨砕し，遠心分離によつて 分画して行くと，細胞膜だけを集めることができる。こ のものをさらに脱脂した後， $1 \mathrm{~N}-\mathrm{KOH}$ を用いて抽出す る。抽出液在硫安を用いて兟析した。この $\mathrm{KOH}$ 不溶部 にはグルコース:マンノース 95:5の栯蛋白が含まれて いるが，扰そらくこのマンノースは不純物であろ5。硫
安塩析部には，グルコース，マンノース比の等しい糖蛋 白が，また非塩析部には，マンノース量が $2 / 3$ を占める 糖蛋白が見出された。

Glucomannan-Protein Complexes from Cell Walls of Yeasts. by G. Kessles and W. J. Nickesson J. Biol. Chem., 234, 2281 5 (1959)

(福 場) 